\title{
Measuring the Motivating Potential Score of Academic Staff at the Lebanese International University
}

\author{
By Bassam Hussein* \\ Hassan Khachfe \\ Amin Haj-Ali \\ Mona Aridi ${ }^{+}$
}

Ever since jobs have been found, motivation remains one of the most important contributors to performance. To measure employees' perceptions of their jobs, in the mid 1970's Hackman and Oldham developed the Job Diagnostic Survey based on the Job Characteristics Theory (JCT). The JCT remains one of the most suitable and widely accepted theories in the field of organizational behavior since it provides a model to perform work design through a set of implementing principles for enriching jobs. The model was tested for the first time ever in a Lebanese university by conducting the standard job diagnostic survey on 294 academic faculty members who work at the Lebanese International University (LIU), Lebanon's largest private university. A standardized scale that assesses the motivating potential score of the job was used and the scores of different academic staff occupying various jobs across several schools varied significantly on all the job characteristics.

Keywords: Job characteristic theory, Job redesign, LIU, Motivating potential score, Organizational behavior.

\section{Introduction and Literature Review}

Throughout history, work is considered central to individuals and society. In any society, developed or developing, work determines the ways of life and patterns of interactions. It serves as a means of nurturing positive feelings and provides motivation to persevere at the workplace. Work provides a major bond through which humans are unified within their respective communities.

One of the earliest theories of motivation was developed by the ancient Greek philosopher Aristotle, who postulated that motivation is associated with an ongoing perception process to control outcomes (Dilts 1994). Starting from

\footnotetext{
${ }^{*}$ Chair, Department of Industrial Engineering, Lebanese International University, Lebanon.

${ }^{\dagger}$ Center for Quality Assurance, Institutional Assessment \& Scientific Research (QAIASR), Lebanon.

* Lebanese International University, Lebanon.

${ }^{+}$Lebanese International University, Lebanon.
} 
1974, Hackman and Oldham conducted their Job Diagnostic Survey as an attempt to make it a measurable assessment tool for job satisfaction. Consequently, in 1975, they designed a well-organized model to perform work design. From that model, they derived a score for motivating the potential of a job in 1976. Ten years later, in 1986, James and Tetrick established a temporal relationship between job characteristics and satisfaction. Based on their assumption, Fried and Ferris assessed the validity of this model; they found a strong correlation between job characteristics and psychological outcomes; then behavioral outcomes in 1987. Consequently, an ample number of theories regarding work motivation by Behson, Eddy, and Lorentzet in 2000 and Humphery, Nahrgang, and Morgeson in 2007, who suggested an expanded model for job characteristics, emerged. Along the same lines, Schjoedt raised the level of research to the field of entrepreneurship in 2009 (Batchelor et al. 2014). What motivates employees has been a continuous and perplexing question addressed by all those theories. As these theories were evolving, three approaches; experienced meaningfulness, experienced responsibility, and knowledge were identified to circumscribe the critical psychological states of the employee (Carolissen and Smith 2014).

\section{Problem Statement}

Job satisfaction is an effective indicator for the success of any business as it motivates the employees to perform their vast duties effectively. Recognition, positive environment and a safe workplace are some of the workforce conditions, which enhance the self-refinement and improve the attitude of the academic staff. In addition, when university management makes decisions without involving academic staff, the staff feels excluded and they may exhibit resistance to change. This may be a signal of job dissatisfaction that drives the business to unfavorable results such as carelessness, weak performance, and low productivity. Unfortunately, because of lack of job satisfaction, academic staff may leave their present institutions for other private or public institutions. For these reasons, academic staff should examine outstanding levels of career contentment and encouragement. The purpose of this study is to compare the elements stimulating job satisfaction and encouragement of non-management academic staff (i.e. Instructor, Lecturer, Assistant Professor, Associate Professor and Professor) at the largest private Lebanese university, LIU.

\section{Methodology: Job Diagnostic Survey}

Many efforts were done in an attempt to increase employees' levels of substantial motivation to fulfill their jobs. The job characteristics model designed by Richard Hackman and Greg Oldham in the 1970s was planned to diagnose and assess jobs for a redesign program based on earlier approaches, which stimulate the motivation and readiness of the employees. They started 
their study by specifying the main job characteristics which contribute to raise the work spirit and boost motivation in the workplace. This model turned to be one of the most popular approaches to job design. They generated a detailed study on the important aspects of organizational behavior and on the effects of the job design on performance, motivation and on job satisfaction (Suman and Srivastava 2009). In this model, they focused on what makes jobs motivating and what turns the good performance to become self-reinforcing.

Hackman and Oldham highlighted five core dimensions that influence motivation and test the fulfillment of the job characteristics of the employees. These dimensions are skill variety, task identity, task significance, autonomy, and feedback. These five core dimensions can be combined to form a single index as Motivating Potential Score (MPS) for a job (Yaverbaum and Culpan 2011).

They started with metering the skill variety for each employee by testing the type of activities done within a job. Besides, they focused on the task identity and task significance for each work being done. These two core dimensions raised the attention to the significance and the identity of the job. Further, they considered the autonomy of the employee in the job to be very effective as a core dimension in the job motivation. Finally, they pointed to the importance and the effectiveness of providing employees with feedback about their work, which boosts their abilities and performance. Table 1 summarizes the conceptuality of each dimension.

Table 1. Conceptuality of the Five Core Dimensions for Measuring MPS

\begin{tabular}{|c|c|c|}
\hline No. & Job Characteristics & Conceptualization \\
\hline 1 & $\begin{array}{c}\text { Skill variety (Item } \\
1,2,3)\end{array}$ & $\begin{array}{l}\text { Degree to which the employees have the scope of using } \\
\text { different skills and talents to complete a variety of work } \\
\text { activities. }\end{array}$ \\
\hline 2 & $\begin{array}{l}\text { Task identity (Item } \\
4,5,6)\end{array}$ & $\begin{array}{l}\text { Degree to which a job requires completion of a whole or } \\
\text { identifiable piece of work, such as doing something from } \\
\text { beginning to end. }\end{array}$ \\
\hline 3 & $\begin{array}{l}\text { Task significance } \\
\quad(\text { Item } 7,8,9)\end{array}$ & $\begin{array}{l}\text { Degree to which the job has a substantial impact on the } \\
\text { organization. }\end{array}$ \\
\hline 4 & $\begin{array}{c}\text { Autonomy (Item } \\
10,11,12)\end{array}$ & $\begin{array}{l}\text { Degree that the employees have freedom in scheduling the } \\
\text { work, determining the procedures and the methods of } \\
\text { work. }\end{array}$ \\
\hline 5 & $\begin{array}{l}\text { Feedback (Item } \\
13,14,15)\end{array}$ & $\begin{array}{l}\text { Degree where the extent to which performing a job } \\
\text { provides an employee with clear information about his or } \\
\text { her effectiveness. }\end{array}$ \\
\hline 6 & MPS & $\begin{array}{l}\text { A measure of the overall potential of a job to foster } \\
\text { intrinsic motivation based on the five core dimensions. }\end{array}$ \\
\hline
\end{tabular}

To better assess the employees' perception of theirs jobs, Hackman and Oldham, built the Job Diagnostic Survey (JDS). They conducted a measurable 
questionnaire consisting of fifteen questions scaled from 1 to 7 (Appendix). By completing this questionnaire, it is possible to compute the MPS of each employee.

The JDS is a simple tool used to detect and identify the weak points affecting the employees' effectiveness and performance (Casey and Robbins 2009).This survey provides quantitative measures through the MPS, which is the measure of the overall potential of a job to enhance substantial motivation. MPS is equivalent to the product of three factors: The average of the first three core dimensions (skill variety, task identity, and task significance), the autonomy, and the feedback. It can be calculated using the following formula (equation 1):

MPS $=\frac{\text { Skill Variety }+ \text { Task Identity }+ \text { Task Significance }}{3} \times$ Autonomy $x$ Feedback

Using this formula, a job can record the lowest score value $1=$ $(1 \times 1 \times 1)$, when the motivation potential of each dimension is the lowest. A job can record the highest score value $343=(7 \times 7 \times 7)$, when the motivation of each dimension is the highest. There is a proportionality between the MPS and it characteristics, that is that the maximal score is recorded when all the characteristics are maximized (Weaver 2006). The score of each core characteristic is the average of the three items in each core characteristic.

\section{Case Study}

To the best of our knowledge and based on extensive research, there is no study that has investigated the motivating potential score for any type of organization in Lebanon. Consequently, our study seems to be the first one to be launched in Lebanon at the Lebanese International University aiming to measure the MPS of the teaching staff. To study the MPS among employees in the school of engineering and in the school of education at LIU, we gave fifteen questions to the employees in both schools and we got 294 responses providing $84.5 \%$ of participation in both schools. This warrants a considerable sample to the significance of this study with respect to the employees in question. Table 2, shows the percentages of respondents in each of the LIU's schools that were covered by the survey.

Table 2. Pecentage of Respondents to the Questionnaire

\begin{tabular}{|c|c|c|c|}
\hline School & All employees & Respondents & $\begin{array}{c}\text { Percentage of } \\
\text { respondents }\end{array}$ \\
\hline Engineering & 72 & 69 & $95.8 \%$ \\
\hline Education & 276 & 225 & $81.5 \%$ \\
\hline Total & 348 & 294 & $84.5 \%$ \\
\hline
\end{tabular}

Source: Adapted from LIU administration and from author's calculation (2014). 


\section{Sample Characteristics}

Before passing the questionnaire over to the teaching staff at those two schools, it is important to identify each respondent according to a category, which might affect the motivating potential score in one way or another. To do so, we designed an ID card for each respondent, which helped us in the discussion later. The five factors affecting the diagnostic process are gender, age, rank, work status, and years of service. In our study, each of these factors is specified in table 3 .

Table 3. Factors Affecting MPS at LIU

\begin{tabular}{|c|c|c|c|c|}
\hline Gender & Age & Rank & Work Status & $\begin{array}{c}\text { Years of } \\
\text { Service }\end{array}$ \\
\hline Male & $25-30$ & Lecturer & Part time & $0-2$ \\
\hline Female & $31-40$ & Instructor & Full time & $2-5$ \\
\hline & $41-50$ & Assistant Professor & & $5-10$ \\
\hline & $51-65$ & Associate Professor & & $10+$ \\
\hline & $65+$ & Professor & & \\
\hline
\end{tabular}

Source: Suggested by the authors.

The hypotheses tested by this research are as follows:

H1: Females are more motivated than males.

$\mathrm{H} 2$ : The age, rank, and years of service is inversely proportional to motivation.

H3: Part timers are more motivated than the full timers.

Although the study has reached its aims, a number of limitations and cautions couldn't be avoided for many reasons. First of all, the results reflect the motivating potentials of the teaching staff at LIU. In this case, the findings are supposed to be reliable, but in some few cases, if the employees are not satisfied for any reason, they might exaggerate a little bit and this might affect the results; i.e. bias.

Second, in our study, we considered a specific class of employees to answer the questionnaire, excluding the administrative, security, custodian staff, and many others. Consequently, the findings cannot be generalized. The generalizability of the study is limited to the intervention of a single type of employees. More research is coming in the future to include all the remaining schools at LIU spanning across the entire university; namely, School of Pharmacy, School of Business and School of Arts \& Science).

Third, the available MPS benchmark is 128 , which was obtained from excessive studies done on 56 organizations encountering 6,930 respondents handling 876 different jobs in the United States (Udhayanan and Nirmal Raj 2011). The limitation of the international norms of MPS makes the discussion of the results difficult, because the optimal score of MPS differs from one country to another. 
Fourth, when interpreting the results, we took into consideration the weight of the sample under study. As the number of respondents decreases, the reliability of the tool decreases. Specifically, the respondents who participated in the study under some categories (like professors $=7$ out of 294 respondents) do not reflect a clear image of the university (Kass et al. 2011).

Finally, after Hackman and Oldham, a series of improvements and modifications have been done on the Job Diagnostic Model (the Revised Job Characteristic Model (RJCM) by Idaszak and Drasgow in 1987 and the Basic Job Characteristic Model (BJCM) by Boonzaier in 2001 (Boonzaier and Boonzaier 2008). Nevertheless, extensive tests confirmed the reliability of the original model in the educational sector and in the hospitality industries. Accordingly, the original model by Hackman and Oldham still holds in our case.

\section{Calculations}

Using equation 1, we calculated the MPS of each of the employees. Based on the rating of answers given by the employees, involving 294 employees occupying 5 different job grades between $0-10+$ years of service, the response pattern ranged from strongly agree to strongly disagree (where strongly agree $=7$ and strongly disagree $=1$ ). The respondents chose their ratings to the scaled items reflecting their satisfaction in the job. Items on each sub-scale meant for the five characteristics were averaged to obtain a summary score for each of the five job characteristics.

\section{Results}

From the obtained scores, we computed the mean average for each of the five job characteristics, the results are shown in figure 1 .

Figure 1. Average Mean for Each Core Dimension for All the Respondents

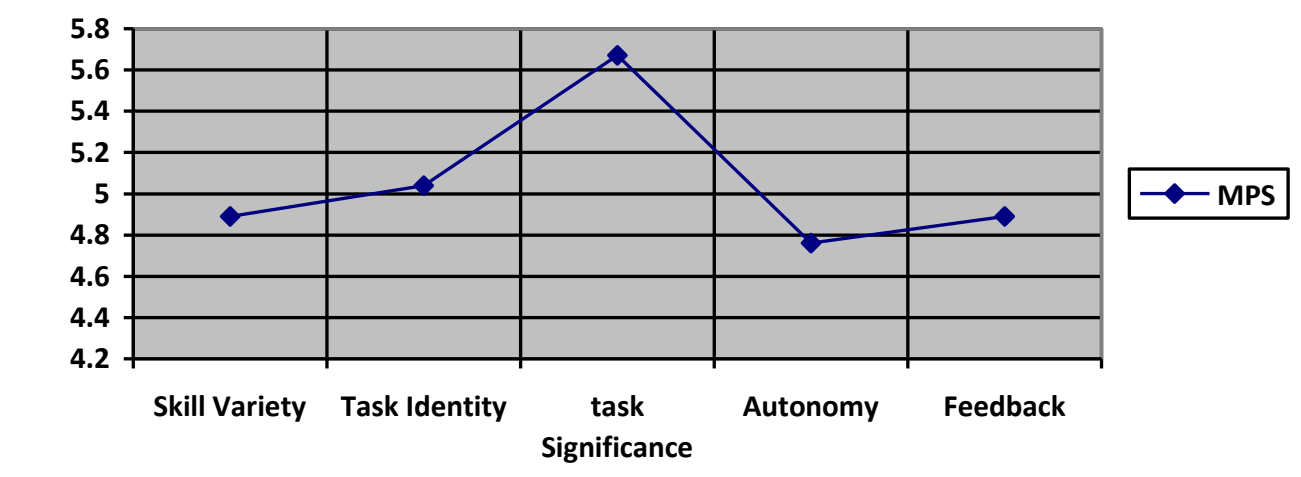

Source: Survey Results and Authors' Calculations. 
The following shows the results of the MPS obtained for the employees at LIU according to the five main factors affecting job satisfaction. Table 4 shows the mean average for each core dimension as compared to each factor.

Table 4. Average Mean for Each Core Dimension Compared to Each of the Five Factors

\begin{tabular}{|c|c|c|c|c|c|c|c|}
\hline No & & $\begin{array}{c}\text { Skill } \\
\text { variety }\end{array}$ & $\begin{array}{c}\text { Task } \\
\text { identity }\end{array}$ & $\begin{array}{c}\text { Task } \\
\text { significance } \\
\end{array}$ & Autonomy & Feedback & MPS \\
\hline \multirow{2}{*}{ 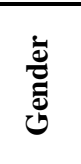 } & Males (98) & 5.03 & 5.06 & 5.67 & 4.59 & 4.84 & 121.34 \\
\hline & $\begin{array}{l}\text { Females } \\
\text { (127) }\end{array}$ & 4.78 & 5.03 & 5.67 & 4.89 & 4.93 & 131.32 \\
\hline \multirow{5}{*}{ 荿 } & $25-30(52)$ & 4.83 & 4.88 & 5.52 & 4.64 & 4.58 & 114.57 \\
\hline & $31-40(92)$ & 4.84 & 4.97 & 5.68 & 4.71 & 4.79 & 121.50 \\
\hline & $41-50(49)$ & 5.07 & 5.14 & 5.74 & 5.02 & 5.27 & 144.61 \\
\hline & $51-65(30)$ & 4.8 & 5.31 & 5.76 & 4.74 & 5.16 & 136.98 \\
\hline & $65+(2)$ & 5.5 & 5.83 & 6.5 & 4.5 & 4.5 & 117.54 \\
\hline \multirow{5}{*}{ 莞 } & $\begin{array}{l}\text { Lecturer } \\
(14)\end{array}$ & 4.67 & 5.14 & 5.33 & 4.29 & 4.79 & 107.54 \\
\hline & $\begin{array}{l}\text { Instructor } \\
(155)\end{array}$ & 4.86 & 5.09 & 5.72 & 4.89 & 4.94 & 132.67 \\
\hline & $\begin{array}{l}\text { Assistant } \\
\text { Prof. (42) }\end{array}$ & 4.81 & 4.76 & 5.33 & 4.57 & 4.81 & 115.21 \\
\hline & $\begin{array}{l}\text { Associate } \\
\text { Prof. (7) }\end{array}$ & 5.06 & 4.89 & 5.76 & 4.52 & 4.83 & 118.62 \\
\hline & $\begin{array}{l}\text { Professor } \\
\text { (7) }\end{array}$ & 5.05 & 5 & 5.05 & 4.67 & 4.48 & 101.16 \\
\hline \multirow{2}{*}{ 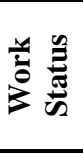 } & $\begin{array}{ll}\text { Part } & \text { time } \\
(164) & \\
\end{array}$ & 4.58 & 5.09 & 5.62 & 4.87 & 4.97 & 131.72 \\
\hline & $\begin{array}{ll}\text { Full } & \text { time } \\
(61) & \\
\end{array}$ & 5.01 & 4.92 & 5.81 & 4.48 & 4.70 & 114.16 \\
\hline \multirow{4}{*}{ 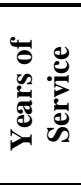 } & $0-2(70)$ & 5.02 & 5.06 & 5.66 & 4.96 & 4.91 & 131.71 \\
\hline & $2-5(70)$ & 4.92 & 4.94 & 5.76 & 4.72 & 4.96 & 127.48 \\
\hline & $5-10(69)$ & 4.73 & 5.16 & 5.66 & 4.68 & 4.75 & 122.91 \\
\hline & $10+(16)$ & 4.88 & 4.85 & 5.44 & 4.44 & 5.15 & 121.45 \\
\hline \multicolumn{2}{|l|}{$\overline{L I U}$} & 4.89 & 5.04 & 5.67 & 4.76 & 4.89 & 121.22 \\
\hline
\end{tabular}

Source: Survey results and authors' calculations

\section{Discussion}

The highest recorded score using MPS was 300 for a management consultant. Hackman and Oldham suggest that an average motivating potential score for jobs in U.S. corporations is around 128 (George and Gareth 2012).

Unfortunately, a benchmark norm for MPS has not been established yet; normative data are still being accumulated on the JDS scale.

The results obtained according to each dimension taking into account the five identification factors of the employees are presented in detail in the following sections. 


\section{Skill Variety}

Regarding skill variety, we noticed that the mean slightly changes between 4.67 for lecturers and 5.07 for staff aged between 41 and 50 years of age.

Considering the rank, it is clearly noticed that associate professors have a wide variety of tasks handle as they recorded 5.06. We found a similar pattern of results regarding the age of the staff belonging to the interval [41 - 50]; the faculty within this range are mostly assistant and associate professors. On the other hand, the full-timers use different skills and talents to fulfil their job; whereas, the part-timers have a definite part of job that is repeated over and over again; this might refer to their commitment to other jobs or institutions. Furthermore, the new employees encounter a wide variety of tasks and activities scoring 5.02.

\section{Task Identity}

The task identity scored 5.04 as an average for all the employees. This means that the job is moderate-sized compared to the overall piece of work. Considering the five main factors, it seems that task identity is above average for most of them. However, the lecturers recorded the highest score (5.14) as their job involves doing the whole piece of work, from start to finish; whereas, the associate professors and the assistant professors recorded lower grades. This is obviously justified by the fact that professors need assistants to accomplish their job. They can run on more than one task handled by others.

\section{Task Significance}

The task significance recorded 5.67, the highest score among all dimensions. As an overall average, we can say that most the tasks encountered by the educators at LIU are significant. Zooming in, we can find a direct proportionality between the task significance and the ages. Besides, the results show that the tasks handled by the full timers are more significant than those handled by the part timers. This is rational as the full timers have administrative work to do in addition to their teaching tasks.

\section{Autonomy}

On the autonomy dimension, an overview indicated 4.76 as an average mean. This means that many things are standardized and not under the control of workers, but they can make some decisions about the work like scheduling or determining the procedure of the work. Considering the five main factors, we can clearly notice that the average increases with the rank of the job. On the other hand, females tend to be more independent in scheduling their work and taking some decisions. 


\section{Feedback}

The feedback recorded an average of 4.89 as an overview of the whole sample. Table 2 shows that females care more about the feedback of their work with a score of 4.89 and the employees aged between 41 and 50 years of age marked the highest rank of 5.27. According to Hackman and Oldham, this average indicates that sometimes doing the job provides "feedback" to the employee; sometimes it indicates an uncertainty concerning the degree where the extent to which performing a job provides an employee with clear information about his or her effectiveness.

\section{Motivating Potential Score (MPS)}

An examination concerning gender equality shows that the motivation potential score of the females (131.32) is higher than that of the males (121.34), which implies that the females tend to be more satisfied in their jobs than males. This shows that the first hypothesis is true.

The age of the employee plays a vital role in rating the motivation potential score. The MPS of the middle-aged employees is the highest (144.61), this indicates that the employees are mostly satisfied when they already demonstrated their capabilities, tried different tasks, and had a considerable experience. In other words, they mastered their roles and got used to what they are doing.

The rank of the job stands as an important factor for the employees' motivating. Scientifically speaking the MPS should increase with the rank of the job. However, our findings recorded the highest MPS for the instructors (155 respondents) with 132.67 and the lowest 101.16 for the professors (7 respondents). These results cannot be generalized considering the covered sample in each category, we cannot build our judgement on seven professors; we need at least numbers between 100-1000 participants to make any scientific discussion (Weaver 2006).

For the years of service, the results show a negative strong correlation between the MPS and the years of service of the employees at LIU. Starting with the first two years of service, the MPS of the employees is high (131.71). This score decreases as the years of service increases, ending up with 121.45 for those who served for more than ten years. This could be because senior faculty members' expectations tend to be higher as they spend more time in their respective roles or institutions.

The results for each of the age, rank, and years of service show that there is a negative correlation between each of those factors and motivation. However, we have noticed an exception regarding the lecturers and the young faculty members (aged between 25 and 40) as they recorded the lowest motivation. This implies that the second hypothesis is true with an exception.

Finally, the results show that the full timers need more motivation to improve their performance, which proves the third hypothesis. They scored 114.16, which is due to the variety and intensity of duties and tasks that mirror 
their full commitment to the university. It is clear that the MPS for part timers is pretty good (131.71), as they are not exhausted by the full time duties and its consequences.

All the five factors combined, contribute to the variation of the motivating potential score. Considering a high-level view on the sample, we found that the MPS for the LIU faculty, in both schools under study, is 121.22. Compared to the USA norm compiled by Hackman and Oldham (128) and to the MPS for the manufacturing field (111.35) in Michigan (Philips 2012), we can say that this score is relatively good.

\section{What next?}

A vast array of job redesign models has been emerged in an attempt to raise the employees' motivation, such as job enrichment, job enlargement, and scientific management. All the executed redesign models focus on re-arranging the tasks and the duties of the employees. However, job redesign is much easier if we consider re-arranging those tasks according to the five core dimensions. Hence, according to the defect obtained by the scores of the five dimensions, we can do our adjustment.

Taking into account the evenness of the five core dimensions, a change can be made on the level of structural empowerment by combining tasks to enrich the skills of the employees, by grouping tasks to raise the significance of the job, or maybe by opening feedback channels so that employees can monitor their performance.

Furthermore, to increase motivation, managers must focus on the validity of the three critical psychological states suggested by Hackman and Oldham. Consequently, the employees are supposed to experience the meaningfulness of their work, the responsibility regarding work outcomes, and the knowledge of the results to know how they are performing their jobs.

For example, in our case, employees with more than ten years of service are provided with feedback of their work more than the new employees, and hence the new employees are less satisfied. In order to increase satisfaction for those employees, we recommend increasing the recognition by increasing the follow up process including the appreciation of their work.

Moreover, the autonomy of the part-timers is higher than that of the fulltimers, which indicates that the employees with a full time job should be motivated more by providing them with a wider space of autonomy as they are supposed to handle many different tasks within their job.

\section{Conclusion and Further Research}

A study of MPS at LIU revealed that JCM is applicable for enriching the setting of a job at the university. According to the study this model still holds especially in the educational sector where satisfaction is an essential factor in the delivering process. Surprisingly, in a developing country like Lebanon the 
MPS (121.22) is close to the average scored in the United States (128) as suggested by Hackman and Oldham (Hackman and Oldham 1976). Conclusively, globalization might have played an important role in aligning most of the ongoing advancements all over the world.

Diagnosing the motivation of the employees is the first step towards a radical improvement in a dramatic competitive world. The Job Diagnostic Model serves as a substantial tool in the hands of the managers. Through this tool, entrepreneurs are enabled to monitor the serious gabs starring at their organization. Further, they can derive remedial actions and formulate comprehensive arrangements to enhance the work motivation among employees.

The current study investigated the motivation levels of the teaching staff focusing on the intrinsic satisfaction of the employees from a personal perspective. More research should be done to identify the extrinsic factors that might influence the job satisfaction. The combination of the intrinsic and extrinsic factors of job satisfaction helps us in zooming out the whole figure of determining motivation from different aspects.

As for this study, it is far from being complete and it is an ongoing project, which will be carried out year after year until it covers a bigger sample all across LIU and even beyond by expanding it to other universities. Consequently, more research into this study is still necessary before obtaining a comprehensive motivating potential score for university education or other sectors in Lebanon.

\section{Appendix}

Kindly, answer each of the fifteen questions honestly and frankly.

Table 5. Job Diagnostic Survey on Five Core Dimensions

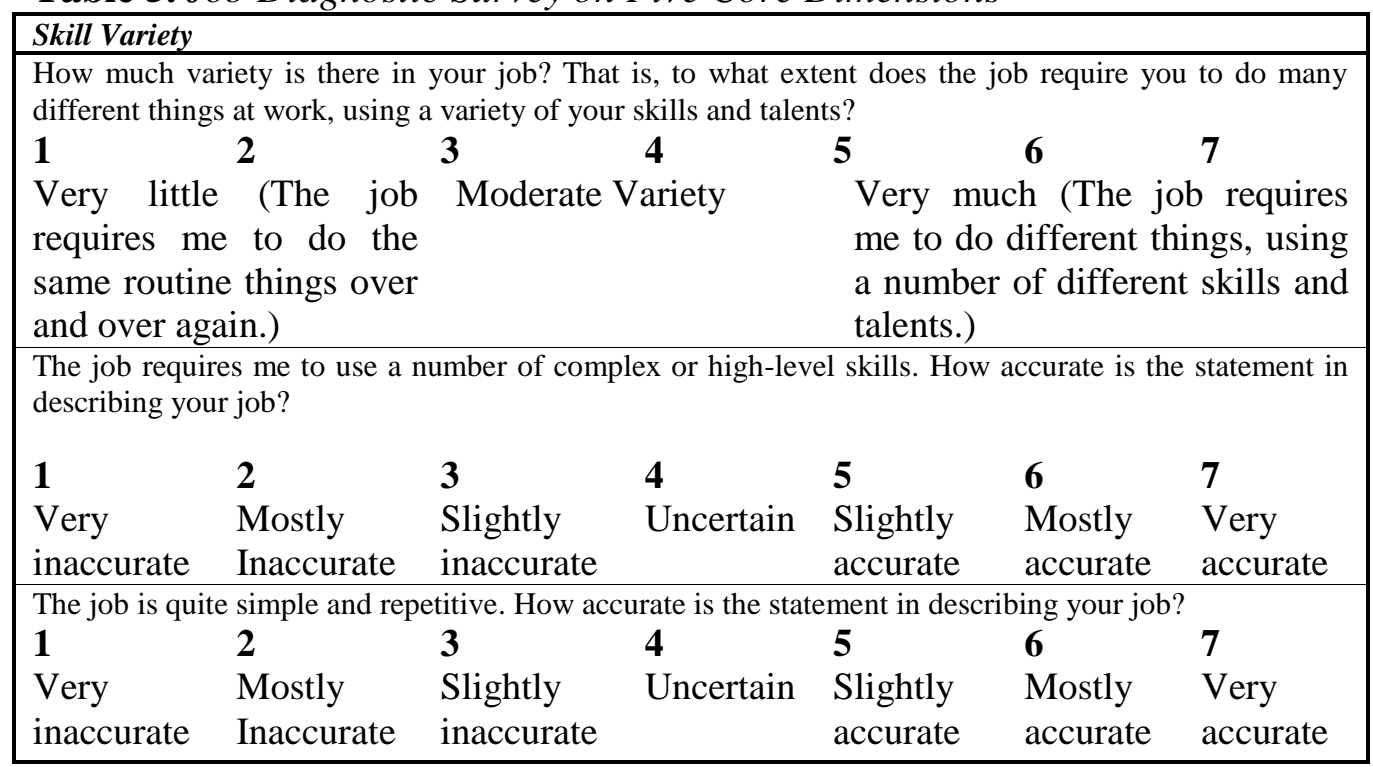




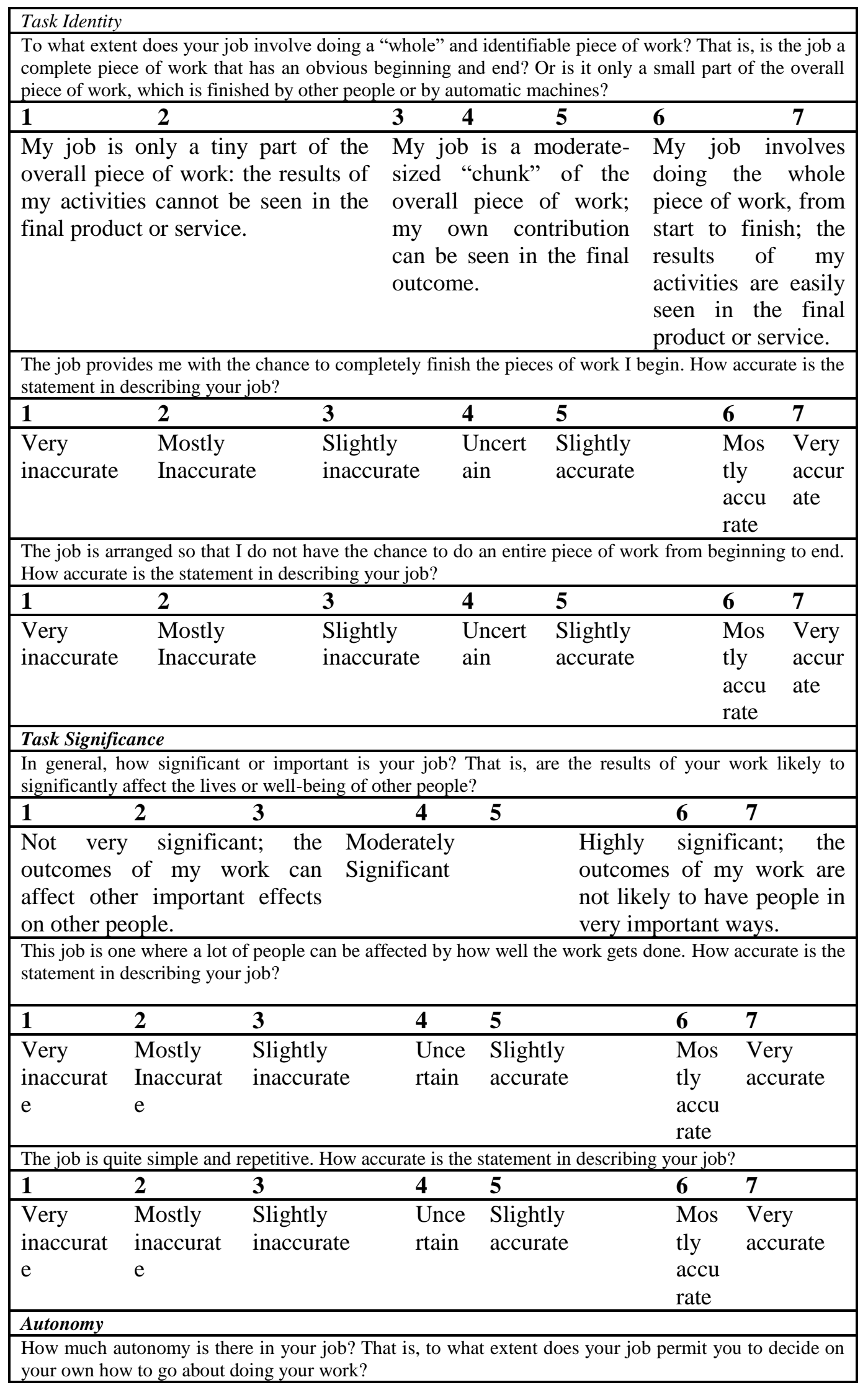




\begin{tabular}{|c|c|c|c|c|c|c|}
\hline 1 & 2 & 3 & 4 & 5 & 6 & 7 \\
\hline $\begin{array}{l}\text { Very little; } t \\
\text { me almost } \\
\text { "say" abou } \\
\text { when the wo }\end{array}$ & $\begin{array}{l}\text { ob gives } \\
\text { personal } \\
\text { ow and } \\
\text { is done. }\end{array}$ & $\begin{array}{l}\text { Moderate a } \\
\text { things are sta } \\
\text { under my cc } \\
\text { make some d } \\
\text { work. }\end{array}$ & $\begin{array}{l}\text { onomy; } \\
\text { ardized } \\
\text { trol, but } \\
\text { isions ab }\end{array}$ & $\begin{array}{l}\text { many } \\
\text { and not } \\
\text { I can } \\
\text { out the }\end{array}$ & $\begin{array}{l}\text { Very much; } \\
\text { gives me } \\
\text { complete resp } \\
\text { for deciding } \\
\text { when the work }\end{array}$ & $\begin{array}{l}\text { the jobs } \\
\text { almost } \\
\text { onsibility } \\
\text { now and } \\
\text { s done. }\end{array}$ \\
\hline $\begin{array}{l}\text { The job give } \\
\text { accurate is th }\end{array}$ & $\begin{array}{l}\text { siderable } \\
\text { nt in desc }\end{array}$ & $\begin{array}{l}\text { ppportunity for } \\
\text { ibing your job? }\end{array}$ & ependence & and freedo & $\mathrm{m}$ in how & work. How \\
\hline 1 & 2 & 3 & 4 & 5 & 6 & 7 \\
\hline $\begin{array}{l}\text { Very } \\
\text { inaccurate }\end{array}$ & $\begin{array}{l}\text { Mostly } \\
\text { inaccurat } \\
\text { e }\end{array}$ & $\begin{array}{l}\text { Slightly } \\
\text { inaccurate }\end{array}$ & $\begin{array}{l}\text { Uncer } \\
\text { tain }\end{array}$ & $\begin{array}{l}\text { Slightly } \\
\text { accurate }\end{array}$ & $\begin{array}{l}\text { Mos } \\
\text { tly } \\
\text { accu } \\
\text { rate }\end{array}$ & $\begin{array}{l}\text { Very } \\
\text { accurat } \\
\text { e }\end{array}$ \\
\hline The job der & chance & $\begin{array}{l}\text { my perso } \\
\text { your job? }\end{array}$ & ative $c$ & $\overline{\text { udgme }}$ & carrying out & \\
\hline 1 & 2 & 3 & 4 & 5 & 6 & 7 \\
\hline $\begin{array}{l}\text { Very } \\
\text { inaccurate }\end{array}$ & $\begin{array}{l}\text { Mostly } \\
\text { inaccurat } \\
\text { e }\end{array}$ & $\begin{array}{l}\text { Slightly } \\
\text { inaccurate }\end{array}$ & $\begin{array}{l}\text { Uncer } \\
\text { tain }\end{array}$ & $\begin{array}{l}\text { Slightly } \\
\text { accurate }\end{array}$ & $\begin{array}{l}\text { Mos } \\
\text { tly } \\
\text { accu } \\
\text { rate } \\
\end{array}$ & $\begin{array}{l}\text { Very } \\
\text { accurat } \\
\text { e }\end{array}$ \\
\hline
\end{tabular}

Feedback

To what extent does doing the job itself provide you with information about your work performance? That is, does the actual work itself provide clues about how well you are doing-aside from any "feedback" coworkers or supervisors may provide?

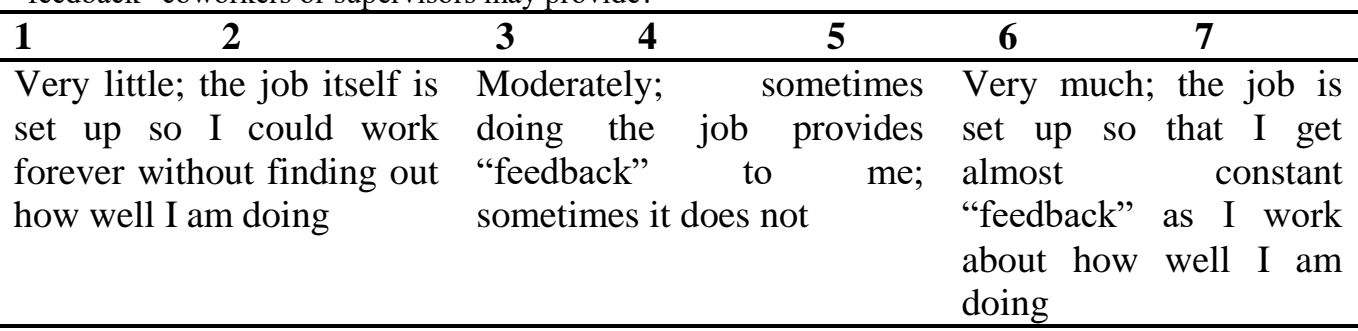

Just doing the work required by the job provides many chances for me to figure out how well I am doing. How accurate is the statement in describing your job?

\begin{tabular}{|lllllll|}
\hline $\mathbf{1}$ & $\mathbf{2}$ & $\mathbf{3}$ & $\mathbf{4}$ & $\mathbf{5}$ & $\mathbf{6}$ & $\mathbf{7}$ \\
\hline $\begin{array}{l}\text { Very } \\
\text { inaccurate }\end{array}$ & $\begin{array}{l}\text { Mostly } \\
\text { inaccurate }\end{array}$ & $\begin{array}{l}\text { Slightly } \\
\text { inaccurate }\end{array}$ & Uncertain & $\begin{array}{l}\text { Slightly } \\
\text { accurate }\end{array}$ & $\begin{array}{l}\text { Mostly } \\
\text { accurate }\end{array}$ & $\begin{array}{l}\text { Very } \\
\text { accurate }\end{array}$ \\
\hline $\begin{array}{l}\text { The job itself provides very few clues about } \\
\text { statement in describing your job? }\end{array}$ & $\mathbf{2}$ & $\mathbf{3}$ & $\mathbf{4}$ & $\mathbf{5}$ & $\mathbf{6}$ & $\mathbf{7}$ \\
\hline $\mathbf{1}$ & Mostly & Slightly & Uncertain & Slightly & Mostly & Very \\
Very & inaccurate & & accurate & accurate & accurate \\
inaccurate & inaccurate & inacrorming & well. How accurate is the \\
\hline
\end{tabular}

Source: George and Jones: Understanding and Managing Organizational Behavior (2012, 189-191).

\section{References}

Batchelor JH, Abston KA, Lawlor KB, Burch GF (2014) The job characteristics model: An extension to entrepreneurial motivation. Small Business Institute Journal 10(1): 1-10. 
Boonzaier B, Boonzaier M (July 2008) From Sweatshops to sweetshops - job redesign as an innovation for sustaining call centres. 16th Annual Conference of Pacific Basin Finance Economics Accounting Management. Brisbane, Australia.

Carolissen LK, Smith DC (2014) Motivating IT staff in a government organisation in South Africa. Kowledge Production and Innovation Conference: 61-71. Cape Town, South Africa: Retrieved from http://bit.ly/1YK5s8A. [Accessed 20 April 2015].

Casey R, Robbins J (2009) A comparison of the elements of motivation in the hospital industry versus the retail and manufacturing sectors. Journal of Diversity Management 4(3): 13-20.

Dilts RB (1994) Strategies of Genius Vol. 1. Capitola, California: Meta Publications.

George JM, Gareth JR (2012). Understanding and managing organizational behavior. In JM George, GR Jones Understanding and Managing Organizational Behavior $6^{\text {th }}$ edition: 188-199. New Jersey, USA: Pearson Education, Inc., publishing as Prentice Hall.

Hackman RJ, Oldham GR (1976) Motivation through the design work: Test of a theory. In JR. Hackman, GR Oldham Organizational Behavior and Human Performance: 250-279). New York: Academic Press, Inc.

Kass SJ, Vodanovich SJ, Khosravi JY (2011) Applying the Job Characteristics Model to the College Education Experience. Journal of the Scholarship of Teaching and Learning 11(4): 56-68.

Philips MS (2012) Knowledge management, job design, and organizational climate's influence on employees' perception of quality. Ypsilanti, Michigan.

Suman S, Srivastava AK (2009) The measurement of job characteristics in context to indian work scenario. Journal of Indian Academy of Applied Psychology 35 (Special Issue): 142-147.

Udhayanan P, Nirmal Raj A (2011) A revisit on the application of Hackman and Oldham Model in Organizations. International Journal of Research in Commerce and Management 2(2): 78-85.

Weaver SJ (2006) Characteristics for success: predicting intervention effectiveness with the job characteristics model. Orlando, Florida.

Yaverbaum GJ, Culpan O (2011) Foundations for understanding the user environment: A Study for motivation, task differences, and technology. Journal of Applied Business Research (JABR) 4(4): 97-104. 